УДК 658.6 (339.6)

DOI: https://doi.org/10.37320/2415-3583/11.17

Сергєєва O.P.

кандидат наук з державного управління, доцент,

Університет імені Альфреда Нобеля

ORCID: https://orcid.org/0000-0001-9823-1648

\title{
ТОВАРООБІГ В УКРАЇНІ - РЕАЛІЇ СЬОГОДЕННЯ
}

\begin{abstract}
У статті досліджено сучасний стан товарообігу в Украӥні на основі відкритої публічної статистичної інформаиї. Проведено дослідження основних показників розвитку сфери роздрібного та оптового товарообігу за 2014-2018 рр. в Украӥні. У результаті иього аналізу зроблено висновки, щзо роздрібна та оптова торгівля мають як негативні, так і позитивні моменти розвитку. Досліджено, щзо товарообіг в Украӥні представлений продовольчими і непродовольчими товарами. Серед роздрібного й оптового товарообігу переважають непродовольчі товари. Проведено аналіз обсягу реалізованої продукиії (робіт, послуг), за результатами якого можемо із впевненістю сказати, щьо товари, які продаються в оптовій та роздрібній торгівлі, займають велику питому вагу. Зроблено висновки, щз в період жорсткого карантину підприємства оптової і роздрібної торгівлі перебувають у складних умовах господарювання, деякі навіть припинили свою діяльність, а деякі терпляче чекають на відновлення минулих обсягів роботи. За таких умов підприємствам щзо перебувають у кризовій ситуаиії, потрібні державна підтримка, пільгове кредитування або проведення оздоровчих процедур.
\end{abstract}

Ключові слова: товарообіг, оптова торгівля, роздрібна торгівля, продовольчі товари, непродовольчі товари, карантин, підприємства, споживання, реалізація.

Постановка проблеми. Товарообіг визначає розмір користування матеріальними благами, виражає фінансові відносини, які утворюються під час переміщення товарів зі сфери виготовлення та обігу у сферу індивідуального користування. Суть товарообігу виражається у фінансових відносинах, пов'язаних $з$ обміном товарів та послуг у процесі купівлі-продажу.

Торгівля $\epsilon$ найважливішою галуззю формування і стабілізації споживчого ринку, координуючою ланкою в системі міжгалузевих, регіональних та міжрегіональних зв'язків, дієвим механізмом задоволення соціальних потреб, сприяє ефективному розвитку виробництва i впливає на формування його обсягів і перспективних напрямів. Сучасний розвиток національної економіки характеризується поступовою трансформацією, зумовленою впливом євроінтеграційних процесів, лібералізації у сфері зовнішньоекономічної діяльності, дестабілізації глобальних торговельних регуляторів та залучення країн у міжнародні економічні відносини.

Сьогодні в Україні простежується зменшення рівня рентабельності діяльності підприємств, що означає збитковість деяких торговельних підприємств. Ця ситуація визначає потребу у вивченні реалій сьогодення щодо функціонування оптової і роздрібної торгівлі в Україні та її впливу на темпи і співвідношення соціального відтворення.

Аналіз останніх досліджень і публікацій. Товарообіг посідає істотне місце у соціальному відтворенні та вважається однією 3 ключових категорій економічної науки, має прямий вплив на розвиток та формування рівня життя жителів держави. Тому вивченню його розвитку присвячені праці багатьох вітчизняних і зарубіжних науковців, таких як: В. Апопій, І. Височин, Н. Голошубова, С. Давиденко, Я. Жаліло Ю. Кіндзерський, В. Лагутін, А. Мазаракі, О. Мазур, В. Точилін, В. Торопков, М. Якубовський та інші.

Мета статті полягає у здійсненні аналізу та оцінки сучасного стану товарообігу в Україні, а також виявлення проблем, пов'язаних із діяльністю торговельної галузі.

Виклад основного матеріалу. Товарообіг нині $\epsilon$ одним 3 основних показників господарювання вітчизняних підприємств торгівлі і головним фактором забезпечення сталого розвитку України. 3 метою дослідження закономірностей формування товарообігу необхідно насамперед вивчити основні напрями його зміни.

Як зазначає С.В. Давиденко, «у сфері торгівлі функціонують специфічні економічні відносини, на основі яких установлюється особлива ринкова форма зв'язку між виробництвом і споживанням, забезпечується реалізація товарів і вартості. Зазвичай логічним завершенням процесу товарного виробництва $\epsilon$ реалізація товарів на ринку» [1].

Аналіз літературних джерел засвідчив, що основний акцент робиться на поділі товарообігу на оптовий і роздрібний, таке звуження сфери дослідження привело до відсутності розгорнутої класифікації товарообігу, яка дала би змогу систематизувати види товарообігу і чинники, які на нього впливають, що дозволило би здійснити оптимальний вибір інструментів регулювання як внутрішнього, так і зовнішнього товарообігу.

Розширене відтворення розмірів господарської діяльності і капіталу в період виготовлення нереальне без налагодження торгово-обмінних 
Таблиця 1 - Оптовий та роздрібний товарообіг в Україні у 2014-2018 роках

\begin{tabular}{|c|c|c|c|c|c|c|}
\hline Показники & $2014 \mathrm{p}$ & $2015 \mathrm{p}$ & $2016 \mathrm{p}$ & $2017 p$ & $2018 \mathrm{p}$ & \begin{tabular}{|c|} 
Відхилення \\
\%, в.п.
\end{tabular} \\
\hline Товарообіг оптової торгівлі, млрд грн. & 988 & 1244,2 & 1556 & 1908,7 & 2215,4 & 224,23 \\
\hline Темп приросту, \% & $-8,08$ & 25,93 & 25,06 & 22,67 & 16,07 & 24,14 в.п. \\
\hline Обіг роздрібної торгівлі, млрд грн. & 901,9 & 1031,7 & 1175,3 & 816,6 & 928,6 & 102,96 \\
\hline Темп приросту, \% & 1,47 & 14,39 & 13,92 & $-30,52$ & 13,72 & 12,24 в.п. \\
\hline $\begin{array}{l}\text { Iндекс фізичного обсягу обігу роздрібної } \\
\text { торгівлі (у порівнянних цінах) до відповідного } \\
\text { періоду попереднього року, \% }\end{array}$ & 91,1 & 79,3 & 104,3 & 106,5 & 106,1 & 15,10 в.п. \\
\hline $\begin{array}{l}\text { Скорегований обіг роздрібної торгівлі на } \\
\text { індекс порівняльних цін (приведений до цін } \\
2014 \text { року) }\end{array}$ & 901,9 & 715,2 & 746 & 794,5 & 842,9 & 93,46 \\
\hline $\begin{array}{l}\text { Роздрібний товарооборот підприємств } \\
\text { роздрібної торгівлі юридичних осіб, млрд грн. }\end{array}$ & 438 & 478 & 556 & 586 & 667 & 152,28 \\
\hline Темп приросту, \% & 7,09 & 9,13 & 16,00 & 5,00 & 14,00 & 6,91 в.п. \\
\hline $\begin{array}{l}\text { Роздрібний товарооборот фізичних осіб - } \\
\text { підприємців, млрд грн. }\end{array}$ & 463,6 & 553,7 & 619,3 & 230,2 & 261,5 & 56,41 \\
\hline Темп приросту, \% & 8,07 & 19,43 & 11,85 & $-62,83$ & 13,60 & 5,53 в.п. \\
\hline
\end{tabular}

Джерело: сформовано автором на основі [6]

процесів. У цьому контексті важливо виділити збільшення місткості вітчизняної галузі товарообігу, що характерне для аналізованого періоду 2014-2018 рр. (табл. 1).

Отже, як показують дані таблиці 1, товарообіг оптової торгівлі в Україні за досліджуваний період виріс більш ніж удвічі, що у відсотковому вираження становить $122,23 \%$. Така ситуація привела до збільшення темпу приросту на 24,14 в.п., але поряд із цим спостерігається його поступове зниження в 2016-2018 pp.

Обіг роздрібної торгівлі також збільшився, але лише на 2,96\% (26,7 млн грн.), проте аналіз показав, що в 2017 році відбувся спад номінального обсягу реалізації на 30,52\% (358,7 млн грн.) за рахунок зменшення роздрібного товарообігу фізичних осіб - підприємців на 62,83\% (389,1 млн грн.), що зумовлене змінами податкового законодавства. Саме 3 січня 2017 року підвищили мінімальну заробітну плату до 3600 грн. проти 1600 в 2016 р. та внесли зміни до порядку сплати ЄСВ. Така ситуація привела до того, що роздрібний товарообіг перейшов «у тінь». Роздрібний товарообіг підприємств роздрібної торгівлі юридичних осіб в 2017 році збільшився на 5\%, а в 2018 році збільшився на $14 \%$.

Метод порівняльних цін показав, що скорегований обіг роздрібної торгівлі в 2015 році впав на $20,7 \%$, це пояснюється девальвацією гривні, підвищенням інфляції, ситуацією на Донбасі.

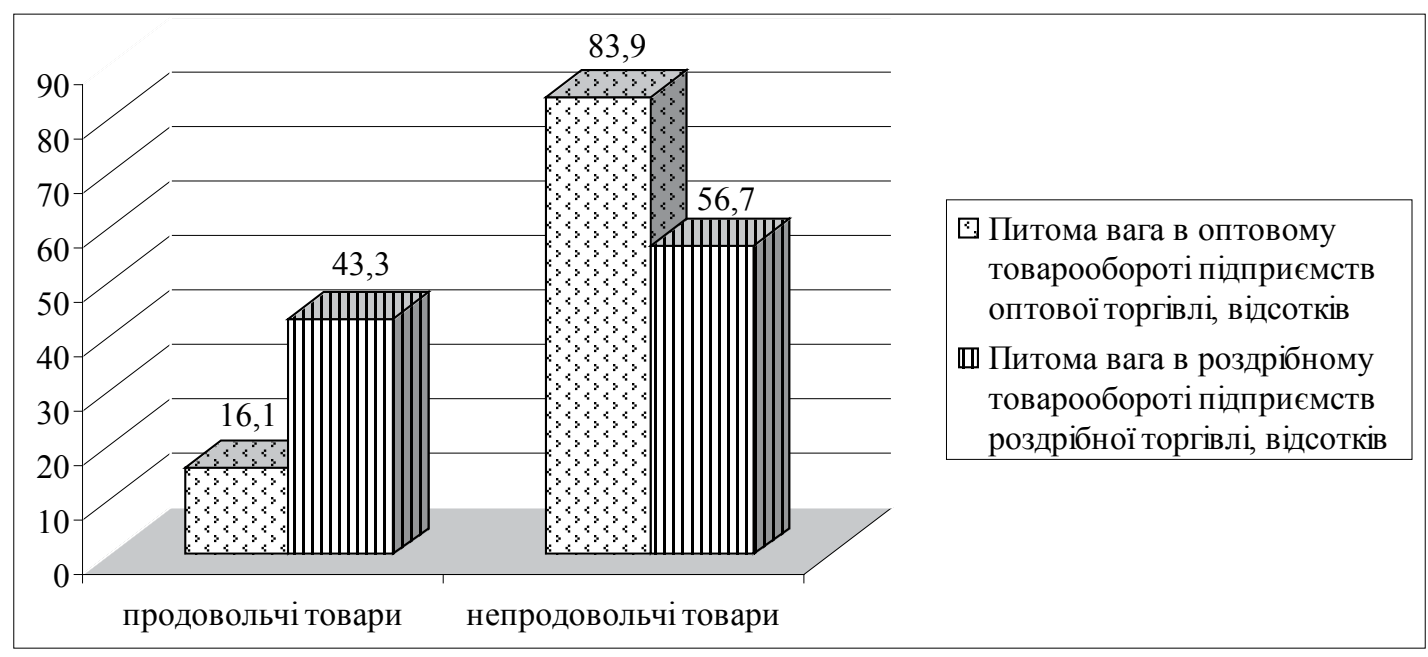

\section{Рисунок 1 - Оптовий та роздрібний товарообіг підприємств оптової та роздрібної торгівлі за 2018 рік}

Джерело: сформовано автором на основі [6] 
Таблиця 2 - Обсяг реалізованої продукції (товарів, послуг) суб'єктів господарювання за видами економічної діяльності

\begin{tabular}{|c|c|c|c|c|c|c|c|c|c|}
\hline \multirow[b]{2}{*}{ Вид економічної діяльності } & \multicolumn{2}{|c|}{2015 p. } & \multicolumn{2}{|c|}{$2016 \mathrm{p}$} & \multicolumn{2}{|c|}{$2017 \mathrm{p}}$. & \multicolumn{2}{|c|}{$2018 \mathrm{p}}$. & \multirow{2}{*}{$\begin{array}{l}2018 p . \\
\text { y\% } \% \\
2015 p\end{array}$} \\
\hline & $\begin{array}{l}\text { млрд } \\
\text { грн. }\end{array}$ & $\%$ & $\begin{array}{c}\text { млрд } \\
\text { грн. }\end{array}$ & $\%$ & $\begin{array}{c}\text { млрд } \\
\text { грн. }\end{array}$ & $\%$ & $\begin{array}{c}\text { млрд } \\
\text { грн. }\end{array}$ & $\%$ & \\
\hline $\begin{array}{r}\text { Сільське, }, ~ \\
\text { госпо }\end{array}$ & 372 & 6,5 & 414,8 & $\mathbf{6 , 0}$ & 467,6 & $\mathbf{5 , 5}$ & $\mathbf{5 3 2 , 5}$ & 5,3 & 143,1 \\
\hline Промисловість & 1917,2 & 33,5 & 2343 & 34,1 & 2862,3 & 33,8 & 3300,7 & 33,0 & 172,2 \\
\hline Будівництво & 150,5 & 2,6 & 181 & 2,6 & 236,5 & 2,8 & 308,8 & 3,1 & 05,2 \\
\hline Оптова та роздрібна торгівля & 2159,3 & 37,8 & 2628,7 & 38,2 & 3351,2 & 39,6 & 3983,6 & 39,8 & 184,5 \\
\hline Транспорт & 322,3 & 5,6 & 398,9 & 5,8 & 479 & 5,7 & 560,5 & 5,6 & 173,9 \\
\hline Фінансова та с & 236,5 & 4,1 & 214,4 & 3,1 & 222,5 & 2,6 & 282,9 & 2,8 & 119,6 \\
\hline Інші види економічної діяльності & 558,6 & 9,8 & 696,3 & 10,1 & 847,9 & 10,0 & 1028,6 & 10,3 & 184,1 \\
\hline Усього & 5716,4 & 100,0 & 6877,1 & 100,0 & 8467 & 100,0 & 9997,6 & 100,0 & 174,9 \\
\hline
\end{tabular}

Джерело: сформовано автором на основі [6]

32016 року спостерігається поступове підвищення купівельної спроможності та фізичних обсягів споживання товарів за рахунок зміцнення гривні.

Товарообіг в Україні представлений продовольчими і непродовольчими товарами, їхня питома вага в оптовому та роздрібному товарообігу підприємств за 2018 рік наведена на рис. 1.

Таким чином, згідно зі Статистичним щорічником України за 2018 рік, 56,7\% роздрібного товарообігу становить непродовольча група товарів, $43,3 \%$ - продовольча. В оптовій торгівлі непродовольчі товари мають ще більшу частку $(83,9 \%)$, а непродовольчі - нижчу $(16,1 \%)$.

Одним із важливих аспектів дослідження структури товарообігу є дослідження обсягу реалізованої продукції (товарів, послуг) на території України [3], цей аналіз наведений у таблиці 2.

Провівши аналіз обсягу реалізованої продукції (робіт, послуг), можемо із впевненістю сказати, що товари, які продаються в оптовій та роздрібній торгівлі, займають велику питому вагу: від $37,8 \%$ в 2015 р. до $39,8 \%$ в 2018 р., сума виросла на $84,5 \%$ (160,5 млрд грн.). Поряд із реалізацією товарів оптової і роздрібної торгівлі значну частину займають товари $з$ промисловості, які становлять $33 \%$ у 2018 р. Натомість значною мірою протягом 2015-2018 рр. зменшилася частка фінансової та страхової діяльності в обсягах реалізованої продукції (з 4,1\% у 205 р. до 2,8\% у 2018 р.). Підводячи підсумки, можемо сказати, що за досліджуваний період обсяг реалізованої продукції (товарів, послуг) збільшився на 4281,2 млрд грн., або на $74,9 \%$, в основному за рахунок збільшення цін.

Офіційна статистика дає можливість проаналізувати дані за попередні роки - це дещо ускладнює дослідження реалій сьогодення у сфері товарообігу. Нині в більшості країн світу й Україні проводяться карантинні заходи через поширення вірусу COVID-19. Одна 3 умов карантину - це обмеження пересування людей, в тому числі і між країнами. Ця ситуація насамперед впливає на туристичну галузь, оскільки закриті кордони між державами.

316 березня 2020 року в Україні введені жорсткі умови карантину, що привело до призупинення роботи торговельних точок, закладів харчування i ринків, це зумовило скорочення товарообігу в країні. На наш погляд, велика кількість працівників, які працюють у комерційній сфері, змушені були піти в неоплачувану відпустку, працівники бюджетної сфери працюють дистанційно, онлайн або $з$ дотриманням жорстких умов карантину.

T. Литовченко наголошує, що «найбільші мережі супермаркетів констатують, що в період карантину їхній товарообіг скоротився, незважаючи на ажіотажний попит у перші дні після введення обмежень. При цьому в деяких магазинах, особливо розташованих у ТРЦ або далеко від житлових районів, зниження товарообігу коливається в діапазоні від 15\% до 70\%. Істотно просіли і торгові точки, розташовані в місцях із високим трафіком - на вокзалах і раніше жвавих вулицях. Вони втратили від 50\% до 80\% товарообігу» [2].

Одна з найбільших мереж АЗС у березні зафіксувала спад продажів бензину майже на $30 \%$. У квітні прогнозують зменшення показників до $50 \%$. Тільки у перший тиждень карантину магазини побутової техніки та електроніки у середньому втратили $54 \%$ продажів. Недорахувалися доходів заклади громадського харчування, яким довелося швидко перепрофільовуватися на послуги доставки. Водночас спад продажів відчули й ті заклади, які доставляли їжу раніше [4].

Таким чином, підприємства оптової і роздрібної торгівлі перебувають у складних умовах господарювання, деякі навіть припинили свою діяльність, а деякі терпляче чекають на відновлення минулих обсягів роботи. За таких умов підприємствам, що знаходяться в кризовій ситуації, потрібні державна підтримка, пільгове кредитування або проведення оздоровчих процедур. Останні, на думку деяких науковців, $є$ «проце- 
сом запровадження системи заходів зі зниження витрат і ризиків, спрямованих на усунення неплатоспроможності, відновлення фінансової стійкості та забезпечення економічної рівноваги на тривалий період» [7].

Послаблення карантинних умов значною мірою позитивно вплине на товарообіг у країні, адже більшість працівників повернуться на робочі місця, відновиться співпраця між підприємствами у сфері обміну товарами.

Висновки. Отже, Статистичні дані за 2014-2018 рр. свідчать про зростання оптового та роздрібного товарообігу в Україні та обсягів реалізованої продукції (товарів, послуг). Серед роздрібного й оптового товарообігу переважають непродовольчі товари. За результатами проведе- ного аналізу із впевненістю можемо сказати, що товари, які продаються в оптовій та роздрібній торгівлі, займають велику питому вагу.

2020 рік в Україні ознаменувався введенням жорстких карантинних заходів через поширення вірусу COVID-19, а також продовженням військових дій на сході країни. У результаті цього зменшився товарообіг в усіх сферах господарювання. Досить відчутна ця ситуація в торговельній сфері, що призвело до припинення діяльності деяких суб' єктів господарювання.

Всі в Україні чекають на зняття або хоча б послаблення карантинних умов, оскільки більшість підприємств, зайнятих у торгівлі, - це малі підприємства, які найбільше страждають від таких умов карантину.

\section{Список використаних джерел :}

1. Давиденко С.В. Вплив розширення внутрішнього ринку на економічне зростання України. Сmpameziчні пріоритети. 2006. № 1. С. 93-101.

2. Литовченко T. Масовий обвал: як скоротилися продажі ритейлерів і чого чекати далі. URL: https://nv.ua/ukr/biz/ experts/karantin-postrazhdali-vsi-riteyleri-azs-produkti-pobutovi-magazini-chogo-chekati-zavtra-novini-ukrajini-50081405. html (дата звернення: 04.05.2020).

3. Системна криза в Україні: передумови, ризики, шляхи подолання. Жаліло Я.А. та ін.; за заг. ред. Я. А. Жаліла. Київ. : НІСД, 2014. 132 с.

4. Скільки втратила торгівля 3 початку карантину: веб-сайт. URL: https://news.finance.ua/ua/news/-/469016/ skilky-vtratyla-torgivlya-z-pochatku-karantynu (дата звернення: 04.05.2020).

5. Статистичний щорічник України за 2018 рік / Державна служба статистики України; За редакцією I. Є. Вернера. Житомир. 2019. 482 с.

6. Ткаченко О.С. Формування механізму економічного оздоровлення сільськогосподарських підприємств: дис. ... канд. екон. наук: 08.00.04. Дніпро, 2017. 198 с.

\section{References:}

1. Davydenko S.V. (2006) Vplyv rozshyrennia vnutrishnoho rynku na ekonomichne zrostannia Ukrainy [Impact of domestic market expansion on Ukraine's economic growth]. Stratehichni priorytety, vol. 1, pp. 93-101.

2. Lytovchenko T. (2020) Masovyi obval yak skorotylysia prodazhi ryteileriv i choho chekaty dali [Mass slump: how retail sales declined and what to expect next]. Available at: https://nv.ua/ukr/biz/experts/karantin-postrazhdali-vsi-riteyleri-azs-produkti-pobutovi-magazini-chogo-chekati-zavtra-novini-ukrajini-50081405.html (accessed 04 May 2020).

3. Zhalilo Ya.A. (2014) Systemna kryza v ukraini peredumovy ryzyky shliakhy podolannia [Systemic crisis in Ukraine: preconditions, risks, ways of overcoming]. Kyiv: NISD. (in Ukrainian).

4. Skilky vtratyla torhivlia $\mathrm{z}$ pochatku karantynu [How much trade has lost since the beginning of quarantine]. Available at: https://news.finance.ua/ua/news/-/469016/skilky-vtratyla-torgivlya-z-pochatku-karantynu (accessed 04 May 2020).

5. Derzhavna sluzhba statystyky Ukrainy (2019), "Statystychnyj schorichnyk Ukrainy za 2018 rik", pp. 482.

6. Tkachenko O.S. (2017) Formuvannia Mekhanizmu Ekonomichnoho Ozdorovlennia Silskohospodarskykh Pidpryiemstv [Formation of mechanism of economic improvement of agricultural enterprises] (PhD Thesis), Dnipro: Dnipropetrovsk State Agrarian and Economic University 
Sergeeva Elena

Alfred Nobel University

\section{TRADE IN UKRAINE - THE REALITY OF TODAY}

The article investigates the current state of trade in Ukraine on the basis of open public statistical information. The main indicators of the development of wholesale and retail retail and wholesale turnover in 2014-2018 in Ukraine were conducted. As a result of this analysis, it is concluded that retail and wholesale trade have both negative and positive development points. It has been researched that the trade turnover in Ukraine is represented by food and nonfood products. Non-food products dominate the retail and wholesale trade. The analysis of the volume of sold products (works, services) on the results of which we can say with confidence that the goods sold in wholesale and retail trade occupy a large share. It is concluded that during the hard quarantine of wholesale and retail trade enterprises are in difficult economic conditions, some have even ceased their activities and some are patiently waiting for the restoration of past work volumes. In such circumstances, businesses in crisis need state support, preferential lending or wellness procedures.

Official statistics make it possible to analyze data from previous years - this makes it difficult to study the realities of today in the sphere of trade. To date, quarantine measures are being implemented in most countries and Ukraine due to the spread of the COVID-19 virus. One of the conditions of quarantine is the restriction of movement of people, including between countries. This situation primarily affects the tourism industry, since the borders between states are closed.

In Ukraine, stringent quarantine conditions were introduced, which led to the suspension of shops, food establishments and markets, which in turn led to a reduction in the country's turnover. In our view, a large number of employees in the commercial sector were forced to go on unpaid leave, employees of the budget sector work remotely, online or subject to strict quarantine conditions. Wholesale and retail businesses are in a difficult business environment, some have even ceased operations and some are patiently waiting for past work to resume. In such circumstances, businesses in crisis need state support, preferential lending or wellness procedures.

Key words: commodity turnover, wholesale trade, retail trade, foodstuffs, non-foodstuffs, quarantine, enterprises, consumption, sale.

JEL classification: L17, L66, L67, L68. 